\title{
Electrocoagulation of bio-filtrated landfill leachate: Fractionation of organic matter and influence of anode materials
}

Dia Oumar ${ }^{1}$, Drogui Patrick ${ }^{2 *}$, Buelna Gerardo ${ }^{3}$, Dubé Rino ${ }^{4}$ and Ben Salah Ihsen ${ }^{5}$

${ }^{1}$ Institut national de la recherche scientifique (INRS-Eau Terre et Environnement), Université du Quebec, 490 rue de la Couronne, Quebec, Qc, Canada, G1K 9A9, email : oumar.dia@ete.inrs.ca

${ }^{2}$ Institut national de la recherche scientifique (INRS-Eau Terre et Environnement), Université du Quebec, 490 rue de la Couronne, Quebec, Qc, Canada, G1K 9A9, Phone : +1 (418) 654-3119, Fax : (418) 654-2600, email: patrick.drogui@ete.inrs.ca

${ }^{3}$ Centre de Recherche Industrielle du Québec (CRIQ), 333 rue Franquet, Québec, QC, Canada, G1P 4C7, email: Gerardo.Buelna@criq.qc.ca

${ }^{4}$ Centre de Recherche Industrielle du Québec (CRIQ), 333 rue Franquet, Québec, QC, Canada, G1P 4C7, email: Rino.Dube@criq.qc.ca

${ }^{5}$ E2Metrix Inc, 3905 Rue Lesage, Sherbrooke, QC, Canada, J1L 2Z9, email: ibensalah@e2metrix.com

\footnotetext{
* Corresponding author
}

July, 2016

Chemosphere 


\section{List of Abbreviations}

$\begin{array}{lll}2 & \text { BFLL } & \text { Bio-filtrated landfill leachate } \\ 3 & \text { TOC } & \text { Total organic carbon } \\ 4 & \text { COD } & \text { Chemical oxygen demand } \\ 5 & \text { HA } & \text { Humic acids } \\ 6 & \text { FA } & \text { Fulvic acids } \\ 7 & \text { Hyl } & \text { Hydrophilic compounds } \\ 8 & \text { UV } & \\ 9 & \text { LL } & \text { Absorbance UV 254 nm }\end{array}$

10

11 


\section{Abstract}

Electrocoagulation (EC) was employed to treat residual organic matter from a landfill leachate pretreated by an aerated bio-filter system. Organic matter (humic acids (HA), fulvic acids (FA) and hydrophilic compounds (Hyl)) was fractionated using DAX-8 resin in order to estimate the efficiency of EC on each fraction. Initial characterization of the bio-filtrated landfill leachate showed that humic substances (HA + FA) represented nearly $90 \%$ of TOC. The effects of current densities, type of anode (Aluminum versus iron), and treatment time on the performance of COD removal were investigated. The best COD removal performances were recorded at a current density ranging between 8.0 and $10 \mathrm{~mA} \mathrm{~cm}{ }^{-2}$ during 20 min of treatment time. Under these conditions, 70\% and 65\% of COD were removed using aluminum and iron electrodes, respectively. Fractionation of organic matter after EC treatment revealed that HA was completely removed using either an aluminum or an iron anode. However, FA and Hyl fractions were partially removed, with the percentages varying from 57 to $60 \%$ and 37 to $46 \%$, respectively. FA and Hyl removal were quite similar using either an aluminum or an iron anode. Likewise, a significant decrease in 254-nm absorbance was recorded ( $\mathrm{UV}_{254}$ removal of 79-80\%) using either type of anode. These results proved that EC is a suitable and efficient approach for treating the residual refractory organic matter from a landfill leachate previously treated by a biological system.

\section{Keywords:}

32 Landfill leachate; Electrocoagulation; Humic acids; Fulvic acids; Bio-filtration. 


\section{Introduction}

The high rate of economic growth and continuing population growth of recent years has led to increasing waste production worldwide. Landfilling is the most common option used to manage this issue [1]. However, landfilling can be problematic if the gases and liquids generated from the decomposition of biosolids are not well captured and treated. These effluents can severely harm the surrounding environment by polluting the atmosphere, the surface, and subsurface water [2]. To prevent this, biogas, mainly composed of methane, is generally captured and burned or used as an energy source. Landfill leachate (LL), on the other hand, needs to be treated before its discharge into the natural environment. However, the complex mixture of organic, inorganic, and microbial pollution found in LL makes it a challenge to simultaneously remove these pollutants.

The characteristics of landfill leachates are influenced by many parameters, but the age of the landfill appears to be the most important [3]. Leachates can be divided into 3 groups, young, intermediary, and mature, according to the age of the landfill. Young LL are generally characterized by high concentrations of COD (COD > $10000 \mathrm{mg} \mathrm{L}^{-1}$ ), with a large proportion of biodegradable compounds (BOD/COD > 0.5) [4]. By comparison, mature LL are characterized by moderate COD values (COD $<5000 \mathrm{mg} \mathrm{L}^{-1}$ ), with a predominance of refractory organic compounds (BOD/COD < 0.5) [5]. Due to their high proportion of biodegradable compounds, young LL are usually treated using biological systems. However, biological technologies are not effective for treatment of mature LL. In order to improve the treatment of mature LL, researchers have examined hybrid systems combining biological (Bio) and non-biological processes. Several approaches have been used for such systems: Bio \& membrane processes [6, 7], Bio \& advanced 
oxidative processes $\left(\mathrm{AOP}_{\mathrm{S}}\right)$ [8], Bio \& physico-chemical processes [9], Bio \& electrochemical treatment $[10,11]$, etc. Depending on the requirements of the treatment, the biological system could be used as a pre- or post-treatment. When it is used as a pretreatment system, its purpose is to reduce mineral and biodegradable organic pollutants in order to reduce the task of the non-biological system. Otherwise, it can be used as a post-treatment system after removing the non-biodegradable compounds using advanced oxidative processes or physico-chemical systems. Either way, biological processes offer the potential to reduce operating costs. These processes can be used to treat biodegradable organic compounds and other inorganic pollutants $\left(\mathrm{NH}_{4}{ }^{+}, \mathrm{PO}_{4}{ }^{3-}\right)$ efficiently and simultaneously. However, after biological treatment, especially in the case of mature landfill leachate, a large proportion of recalcitrant organic molecules such as humic-like substances will remain soluble in the aqueous medium. These humic materials could be a precursor of undesirable organochlorine by-products if the leachate is discharged into a source of drinking water. To avoid this situation, residual organic matter should be reduced or eliminated before discharge. One of the ways to remove such compounds is electrocoagulation (EC). This electrochemical technique has been used for the treatment of raw landfill leachate and other macromolecular compounds, such as humic-like substances, dyes, proteins, etc. [12-14]. EC appears to be effective for the removal of colloids, suspended solids, and other high-molecular-weight compounds. The process generates in-situ coagulant agents using differences in electric potential. These coagulants can agglomerate colloids and generate insoluble metal hydroxides on which organic matter can be adsorbed and co-precipitate. The main reactions occuring in an EC cell can be described in the following equations (Eqs (1), (2) and (3)): 
At the anode: $\quad M_{(s)} \rightarrow M_{(a q)}^{n+}+n e^{-}$

At the cathode: $\quad 2 \mathrm{H}_{2} \mathrm{O}+2 e^{-} \rightarrow 2 \mathrm{OH}^{-}+\mathrm{H}_{2}$

In the bulk solution: $M_{(a q)}^{n+}+n O H^{-} \rightarrow M(O H)_{n_{(s)}}$

where $\mathrm{M}_{(\mathrm{s})}=$ metal, $\mathrm{M}^{\mathrm{n}+}{ }_{(\mathrm{aq})}=$ metallic ion (iron or aluminum ion), $\mathrm{M}(\mathrm{OH})_{\mathrm{n}(\mathrm{s})}=$ metallic hydroxide, and ne ${ }^{-}=$the number of electrons transferred in the reaction at the electrode. It should be noted that Eq. 3 describes a simple case of metallic hydroxide formation. In fact, plenty of complex metallic species may be formed, depending on the $\mathrm{pH}$ level and metal involved [15].

87 In comparison to chemical coagulation, EC offers several advantages, including low salinity of the effluent after treatment, low footprint, reduced production of solid residuals, and easy automation [16].

The main objective of this study was to investigate the effectiveness of EC for the treatment of landfill leachate previously treated by a bio-filter system. The effects of type of anode, current density, and treatment time on the efficiency of the EC process for organic matter removal were investigated. Particular attention was paid to the fractionation of organic matter (humic acids, fulvic acids, and hydrophilic compounds) before and after EC. 


\section{Materials and methods}

\subsection{Characteristics of bio-filtrated landfill leachate}

The LL used in this study was biologically pretreated using an aerated trickling biofilter composed of peat and wood chips. The landfill was pretreated according to the procedure described by Buelna et al. [17]. The raw leachate was collected from the municipal landfill of the city of Saint-Rosaire, Quebec, Canada. The purpose of the biological pretreatment was to remove simultaneously nitrogen, biodegradable organic compounds, and turbidity. The characteristics of the bio-filtrated landfill leachate are presented in Table 1.

\subsection{Electrocoagulation reactor}

EC experiments were carried out in a cylinder reactor in recirculation mode with a batch capacity of $1.5 \mathrm{~L}$ (Fig.1). An external hollow cylinder made of stainless steel served as a cathode, while a full cylinder rod was used as a sacrificial anode. The anodic electrodes were either aluminum or iron. The electrode surfaces that were in contact with the influent were 476 and $1130 \mathrm{~cm}^{2}$ for the anode and the cathode respectively. The current densities cited in the manuscript correspond to the anodic current densities. Current intensity was applied using a Xantrex XFR40-70 power supply (ACA Tmetrix, Mississauga, ON, Canada). No addition of electrolyte salt was required since the conductivity of the bio-filtrated landfill leachate was suitable for an electrochemical treatment. Aliquots of $30 \mathrm{~mL}$ were withdrawn from the reactor at different treatment times. Analyses were performed in the supernatant after at least $1 \mathrm{~h}$ of natural settling (without any flocculent addition). 


\subsection{Characterization of organic matter}

The organic material in the landfill leachate can be divided into 3 groups: humic acids (HA), fulvic acids (FA), and hydrophilic (Hyl) compounds. In order to determine the efficiency of the EC treatment, it was necessary to isolate and evaluate each organic fraction. To do so, several extraction steps were required. The protocol used in this investigation was adapted from a study conducted by Van Zomeren et Comans [18]. Fig. SM1 shows the different separation steps leading to the isolation of each fraction.

The first step (pretreatment) removed suspended solids, colloids, and fats by means of $0.45-\mu \mathrm{m}$ pore size filtration. The sample was then acidified at around $\mathrm{pH} 1.0$ using $6 \mathrm{~N}$ $\mathrm{H}_{2} \mathrm{SO}_{4}$ in order to precipitate the HA fraction. In our case, sulfuric acid was used instead of hydrochloric acid to avoid interference from chloride ions during measurement of the COD. After centrifugation, the HA pallet was dissolved in $0.1 \mathrm{~N} \mathrm{NaOH}$ solution. The supernatant (AF and Hyl) was mixed with a non-ionic and slightly polar resin (Supelite ${ }^{\mathrm{TM}}$ DAX-8, Sigma-Aldrich Co). This resin has the ability to adsorb the FA fraction onto its surface. After one hour of equilibrium, the suspension was then filtrated. The supernatant contained hydrophilic compounds that were not adsorbed onto the resin surface. The DAX-8 resin was then mixed and agitated with $0.1 \mathrm{~N} \mathrm{NaOH}$ solution to desorb the fulvic acids fraction. Analyses of TOC and COD and measurements of absorbance at $254 \mathrm{~nm}$ were carried out in each organic fraction after isolation. 
139

140

141

142

143

144

145

146

147

148

149

150

151

152

\subsection{Analytical methods}

pH was measured using a pH meter (Accumet Excel XL25 - pH / mV / Temp / Ion Meter, Fisher Scientific Co) connected to a double-junction Fisher Scientific Accumet ${ }^{\circledR}$ Electrode (Ag / AgCl reference). Chemical oxygen demand (COD) was measured using the colorimetric method (closed Reflux) certified by the APHA [19], and the absorbance reading was conducted with a UV-Visible spectrophotometer (Cary 50, Varian Canada Inc., Mississauga, ON, Canada). Samples of COD were acidified under pH 2 before analysis. Except for the fractionated organic materials, COD values correspond to total COD. Total Organic Carbon (TOC) was estimated using a Shimadzu TOC 5000A analyzer (Shimadzu Scientific Instruments Inc). Absorbance at $254 \mathrm{~nm}$ was measured in order to assess the degree of aromaticity of each fraction [20] using a UV-Visible spectrophotometer (Cary 50, Varian Canada Inc., Mississauga, ON, Canada). 


\section{Results and discussion}

\subsection{Bio-filtrated landfill leachate characteristics}

Table 1 shows the characteristics of LL after biological treatment. The high variability of the physico-chemical parameters was mainly attributable to seasonal variations in the raw LL used to feed the bio-filtration unit. The large fluctuations in COD were linked to the leaching of humic substances from the bio-filter media (peat and wood chips).

From table 1, it can be seen that the bio-filtration unit significantly reduced the biodegradable carbon, nitrogen, and turbidity. The low alkalinity value of the bio-filtrated landfill leachate was due to mineral carbon uptake by autotroph bacteria during the nitrification process. However, the residual COD concentration was still high after biological treatment. This residual COD was mainly composed of refractory humic-like substances that were difficult for microorganisms to oxidize. In order to understand the nature of these remaining humic substances, fractionation of the organic matter was carried out. The results are presented in Figs. 2a and b.

Figs. 2a and b show that HA and FA represented nearly all the residual organic material in the BFLL. As Fig. 2a shows, the TOC percentages of the fractions were $41 \%$, $50 \%$, and 26\% for HA, FA, and Hyl, respectively. This small percentage of hydrophilic compounds was expected because these compounds are generally more easily oxidized than humic substances. With respect to COD values, the proportions of the organic fractions were slightly different (Fig. 2b), being 56\%, 30\%, and 9\% for the HA, FA, and Hyl fractions, respectively. Despite the fact that the FA fraction contains more carbon in 
175

its molecular structure, its contribution to the COD value was lower than that recorded for the HA fraction. This might be explained by the fact that FA contains more oxygen in its molecular structure (carboxyl and hydroxyl groups) than HA. Since these functional groups are chemically very reactive, less oxygen demand will be required to oxidize the FA molecules. On the other hand, HA contains more carbon in the form of aliphatic chains and aromatic rings, which are more difficult to oxidize.

\subsection{EC of bio-filtrated landfill leachate}

In order to reduce the residual organic compounds in the BFLL, the bio-filtration treatment was followed by EC treatment. Aluminum and iron electrodes were both tested as sacrificial anodes. COD removal at different treatment times and current densities is shown in Figs. 3 and $\mathbf{4}$ for aluminum and iron, respectively. Increases in current density and treatment time were generally beneficial to organic compound removal. This result was expected since the generation of coagulant agents $\left(\mathrm{Al}^{3+}\right.$ and $\left.\mathrm{Fe}^{2+}\right)$ is directly proportional to the applied intensity and time according to Faraday's well-known law. However, beyond a certain level of current density, 8 and $5 \mathrm{~mA} \mathrm{~cm}^{-2}$ for aluminum and iron respectively, we observed that further increases in current density did not significantly affect COD removal. This phenomenon might be explained by the fact that only a specific fraction of organic matter was preferentially removed by the EC treatment. After the removal of this fraction, the remaining organic compounds stayed in soluble form in spite of increases in current density and treatment time. From Figs. 3 and 4, it can be seen that the rate of COD removal was relatively high while current densities of $8 \mathrm{~mA} \mathrm{~cm}^{-2}$ for aluminum electrodes and $5 \mathrm{~mA} \mathrm{~cm}{ }^{-2}$ for iron electrodes were imposed. At these current densities, over 90\% of total COD was removed within the first 15 min. 
After that, COD decreased very slowly until the end of the experience. For the next step of the experiments, the following operating conditions were chosen: $10 \mathrm{~mA} \mathrm{~cm}{ }^{-2}, 20 \mathrm{~min}$ and $8 \mathrm{~mA} \mathrm{~cm}^{-2}$, $20 \mathrm{~min}$ for aluminum and iron, respectively. Under these conditions, 70\% and $65 \%$ of the residual COD was removed using aluminum and iron anodes, respectively. Sludge production was the same (total suspended solids (TSS) of $1.93 \mathrm{~g} \mathrm{~L}^{-1}$ ) for both electrode types under optimum conditions.

\subsection{Partition of organic compounds after electrocoagulation}

To investigate the mechanism behind COD and TOC removal using the EC process, the residual concentrations of the different fractions of organic matter (HA, FA, and Hyl compounds) were evaluated. The results for residual TOC and COD concentrations are presented in Figs. 5 and 6, respectively. From Figs. $\mathbf{5 a}$ and $\mathbf{b}$, it can be seen that EC treatment was very effective at removing the HA fraction: HA was completely removed using either the $\mathrm{Al}$ or the Fe anode. By contrast, the residual Hyl and FA concentrations remained relatively high after the treatment of landfill leachate. Depending on the type of anode used, the percentage of TOC removal for Hyl compounds varied from $37 \%$ to $46 \%$, whereas $57 \%$ to $60 \%$ TOC removal was recorded for the FA fraction. Figs. 6a and $\mathbf{b}$ show the results in terms of residual COD concentrations for $\mathrm{Al}$ and Fe anodes, respectively. As can be seen, all of the COD linked to the HA fraction was removed after EC treatment using either an $\mathrm{Al}$ or an Fe anode. By comparison, only $9.8 \%$ of the COD was removed for Hyl compounds using an $\mathrm{Al}$ anode, and a slight increase in COD concentration (16.9\%) was observed when an Fe anode was used. The Fe anode was more effective than the $\mathrm{Al}$ anode for removal of FA, however, 
27\% and 60\% COD removal recorded for FA compounds using $\mathrm{Al}$ and Fe anodes, respectively.

In sum, the HA fraction was preferentially and totally eliminated during EC of BFLL, while the FA and Hyl compounds were partially removed. This can be attributed to the different molecular weights and surface charges of these three organic fractions. These results are consistent with those of several studies that have characterized the dissolved organic material from landfill leachate and surface water. Physicochemical properties such as hydrophilicity, hydrophobicity, molecular weight, and organic surface charge were studied by these authors [21-26]. Among other results, the studies determined that HA generally have higher molecular weights than fulvic acids and hydrophilic compounds. In addition, the surface of HA and FA is negatively charged because of the presence of certain acidic functional groups, such as carboxyl and hydroxyl groups, which are abundant in humic substances [27]. As a result, humic substances are preferentially removed by the mechanism of adsorption involving electrostatic attraction between the negatively charged humic material and metallic hydroxide complexes, which are positively charged. Since HA have a larger molecular structure than FA and Hyl compounds, they have more ability to interact with metallic hydroxides and co-precipitate. Investigations that have looked at the removal of humic substances from water using chemical coagulation have also found that HA are preferentially eliminated in comparison to the FA fraction [28-31].

The relatively low removal percentage recorded for Hyl compounds is attributable to the low molecular weight of this fraction. Several studies on the use of EC or chemical coagulation have confirmed the inefficiency of these technologies for the removal of 
hydrophilic compounds with low molecular weights [26]. It is worth noting that the TOC linked to the Hyl fraction did not increase during the EC treatment. This suggests that electro-oxidation, transforming the large molecules (such as humic substances) into the small Hyl compounds, did not take place. The large organic molecules were mainly removed by adsorption, coagulation, and co-precipitation.

\subsection{Specific absorbance at $254 \mathrm{~nm}$}

The 254-nm absorbance $\left(\mathrm{UV}_{254}\right)$ of each organic fraction was measured before and after electrochemical treatment in order to estimate the degree of aromaticity of the different fractions.UV $\mathrm{UV}_{254}$ absorbance is linked to organic compounds with one or many double bonds. As can be seen from Fig. 7, the HA fraction had by far the highest value of $\mathrm{UV}_{254}$ absorbance, representing $62 \%$ of the total absorbance of the BFLL. By comparison, FA and Hyl respectively represented only $17 \%$ and $8 \%$ of the total $\mathrm{UV}_{254}$ absorbance. The low result recorded for the FA fraction (3.6 times lower than that recorded for the HA fraction) occurred even though FA had a higher TOC value (TOC $F A$

$=102 \mathrm{mg} \mathrm{C} / \mathrm{L}$ versus $\mathrm{TOC}_{\mathrm{HA}}=85 \mathrm{mg} \mathrm{C} / \mathrm{L}$ ). These results suggest that $\mathrm{HA}$ molecules contain more aromatic rings than FA and Hyl molecules. Since the HA fraction was completely removed after EC, a significant decrease in $\mathrm{UV}_{254}$ absorbance was recorded. The 254-nm absorbance was reduced by $79-80 \%$ using either aluminum or iron anodes. The decrease in $\mathrm{UV}_{254}$ absorbance led also to a decrease in colour due to the high colouring power of HA. Supplementary experiments were performed in order to estimate the colour removal efficiency. It was found that $89 \%$ and $85 \%$ of the true colour was removed using the aluminum and iron anodes, respectively. 
266

267

268 
269

270

271

272

273

274

275

276

277

278

279

280

281

282

283

284

\section{Conclusions}

EC process was applied as tertiary treatment for landfill leachate after a bio-filtration process. Characterization of the BFLL revealed that humic substances (HA and FA) represented nearly $90 \%$ of dissolved organic matter in terms of TOC and COD. The residual organic material was mainly composed of Hyl compounds. Treatment of the BFLL using the EC process removed $70 \%$ and $65 \%$ of total COD using aluminum and iron anodes, respectively. COD removal was most effective at current densities ranging between 8.0 and $10 \mathrm{~mA} \mathrm{~cm}{ }^{-2}$ over 20 min of treatment time. Fractionation of the organic matter remaining after EC showed that the organic fraction linked to HA material was totally removed using either aluminum or iron anodes. The TOC of FA and Hyl compounds was reduced by 57 to $60 \%$ and 37 to $46 \%$, respectively. Measurement of 254nm absorbance revealed that HA contained more aromatic cycles (or more organic Supprimé: compounds with one or many double bonds) than the FA fraction. The HA fraction accounted for $62 \%$ of the total 254-nm absorbance of the BFLL. In all, 79-80\% of 254nm absorbance was removed using either aluminum or iron anodes. 


\section{Acknowledgements}

This research project was conducted in collaboration with the research institutes

289 INRS (Institut National de la Recherche Scientifique) and CRIQ (Centre de Recherche

290 Industrielle du Québec) and the companies E2metrix and Gesterra. It also received the

291 financial support of MITACS (number IT03162). 
1. Hoornweg, D. and P. Bhada-Tata, What a Waste: A Global Review of Solid Waste

2. Lema, J., R. Mendez, and R. Blazquez, Characteristics of landfill leachates and alternatives for their treatment: a review. Water, Air, and Soil Pollution, 1988. 40(3-4): p. 223-250.

3. Kjeldsen, P., M.A. Barlaz, A.P. Rooker, A. Baun, A. Ledin, and T.H. Christensen, Present and Long-Term Composition of MSW Landfill Leachate: A Review. Critical Reviews in Environmental Science and Technology, 2002. 32(4): p. 297-336.

4. Harmsen, J., Identification of organic compounds in leachate from a waste tip. Water Research, 1983. 17(6): p. 699-705.

5. Ehrig, H.-J., Water and Element Balances of Landfills, in The Landfill, P. Baccini, Editor. 1989, Springer Berlin Heidelberg: Berlin, Germany. p. 83-115.

6. Cammarota, M.C., L. Yokoyama, and J.C. Campos, Ultrafiltration, chemical and biological oxidation as process combination for the treatment of municipal landfill leachate. Desalination and Water Treatment, 2009. 3(1-3): p. 50-57.

7. Ince, M., E. Senturk, G. Onkal Engin, and B. Keskinler, Further treatment of landfill leachate by nanofiltration and microfiltration-PAC hybrid process. Desalination, 2010. 255(1-3): p. 52-60.

8. Oller, I., S. Malato, and J. Sánchez-Pérez, Combination of advanced oxidation processes and biological treatments for wastewater decontamination-a review. Science of the total environment, 2011. 409(20): p. 4141-4166.

9. Kurniawan, T.A., W.-h. Lo, and G.Y.S. Chan, Physico-chemical treatments for removal of recalcitrant contaminants from landfill leachate. Journal of Hazardous Materials, 2006. 129(1-3): p. 80-100.

10. Feki, F., F. Aloui, M. Feki, and S. Sayadi, Electrochemical oxidation post-treatment of landfill leachates treated with membrane bioreactor. Chemosphere, 2009. 75(2): p. 25660.

11. Wang, P., I.W. Lau, and H.H. Fang, Electrochemical oxidation of leachate pretreated in an upflow anaerobic sludge blanket reactor. Environ Technol, 2001. 22(4): p. 373-81.

12. Asselin, M., P. Drogui, H. Benmoussa, and J.-F. Blais, Effectiveness of electrocoagulation process in removing organic compounds from slaughterhouse wastewater using monopolar and bipolar electrolytic cells. Chemosphere, 2008. 72(11): p. 1727-1733.

13. Khandegar, V. and A.K. Saroha, Electrocoagulation for the treatment of textile industry effluent-A review. Journal of environmental management, 2013. 128: p. 949-963.

14. Yildiz, Y.S., A.S. Koparal, S. Irdemez, and B. Keskinler, Electrocoagulation of synthetically prepared waters containing high concentration of NOM using iron cast electrodes. Journal of Hazardous Materials, 2007. 139(2): p. 373-380.

15. Dia, O., P. Drogui, R. Dubé, and G. Buelna, Utilisation des procédés électrochimiques et leurs combinaisons avec les procédés biologiques pour le traitement des lixiviats de sites d'enfouissement sanitaires-revue de littérature. Revue des sciences de l'eau/Journal of Water Science, 2016. 29(1): p. 63-89.

16. Drogui, P., J.-F. Blais, and G. Mercier, Review of electrochemical technologies for environmental applications. Recent Patents on Engineering, 2007. 1(3): p. 257-272.

17. Buelna, G., R. Dubé, and N. Turgeon, Pig manure treatment by organic bed biofiltration. Desalination, 2008. 231(1-3): p. 297-304. 
18. Van Zomeren, A. and R.N. Comans, Measurement of humic and fulvic acid concentrations and dissolution properties by a rapid batch procedure. Environmental science \& technology, 2007. 41(19): p. 6755-6761.

19. APHA, Standard Methods for the Examination of Water and Wastewater 20th ed. 1998, Washington, DC, U.S.A: American Public Health Association (APHA).

20. Weishaar, J.L., G.R. Aiken, B.A. Bergamaschi, M.S. Fram, R. Fujii, and K. Mopper, Evaluation of specific ultraviolet absorbance as an indicator of the chemical composition and reactivity of dissolved organic carbon. Environmental Science \& Technology, 2003. 37(20): p. 4702-4708.

21. Comstock, S.E.H., T.H. Boyer, K.C. Graf, and T.G. Townsend, Effect of landfill characteristics on leachate organic matter properties and coagulation treatability. Chemosphere, 2010. 81(7): p. 976-983.

22. Labanowski, J., V. Pallier, and G. Feuillade-Cathalifaud, Study of organic matter during coagulation and electrocoagulation processes: application to a stabilized landfill leachate. J Hazard Mater, 2010. 179(1-3): p. 166-72.

23. Matilainen, A., M. Vepsäläinen, and M. Sillanpää, Natural organic matter removal by coagulation during drinking water treatment: A review. Advances in Colloid and Interface Science, 2010. 159(2): p. 189-197.

24. Mejbri, R., G. Matejka, P. Lafrance, and M. Mazet, Fractionnement et caractérisation de la matière organique des lixiviats de décharges d'ordures ménagères. Revue des Sciences de l'Eau/Journal of Water Science, 1995. 8(2): p. 217-236.

25. Shouliang, H., X. Beidou, Y. Haichan, H. Liansheng, F. Shilei, and L. Hongliang, Characteristics of dissolved organic matter (DOM) in leachate with different landfill ages. Journal of Environmental Sciences, 2008. 20(4): p. 492-498.

26. Zhao, X., X. Wei, P. Xia, H. Liu, and J. Qu, Removal and transformation characterization of refractory components from biologically treated landfill leachate by $\mathrm{Fe}^{2+} / \mathrm{NaClO}$ and Fenton oxidation. Separation and Purification Technology, 2013. 116: p. 107-113.

27. Gu, B., J. Schmitt, Z. Chen, L. Liang, and J.F. McCarthy, Adsorption and desorption of natural organic matter on iron oxide: mechanisms and models. Environmental Science \& Technology, 1994. 28(1): p. 38-46.

28. Croué, J.P., E. Lefebvre, B. Martin, and B. Legube, Removal of dissolved hydrophobic and hydrophilic organic substances during coagulation/flocculation of surface waters. Water Science and Technology, 1993. 27(11): p. 143-152.

29. Hall, E.S. and R.F. Packham, Coagulation of organic color with hydrolyzing coagulants. Journal (American Water Works Association), 1965. 57(9): p. 1149-1166.

30. Sinsabaugh III, R.L., R.C. Hoehn, W.R. Knocke, and A.E. Linkins III, Removal of dissolved organic carbon by coagulation with iron sulfate. Journal (American Water Works Association), 1986. 78(5): p. 74-82.

31. Wu, Y., S. Zhou, X. Ye, D. Chen, K. Zheng, and F. Qin, Transformation of pollutants in landfill leachate treated by a combined sequence batch reactor, coagulation, Fenton oxidation and biological aerated filter technology. Process Safety and Environmental Protection, 2011. 89(2): p. 112-120. 


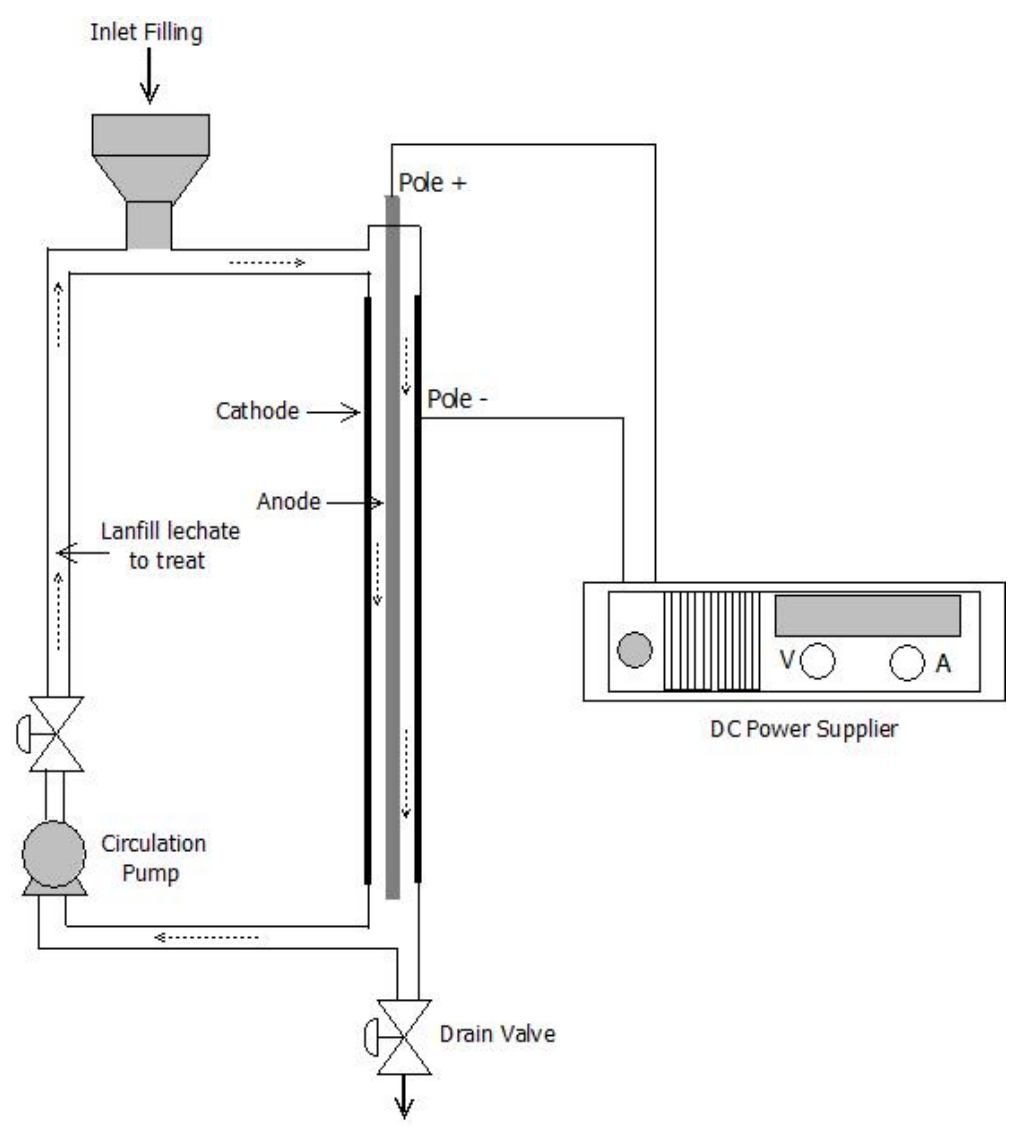


Fig.1. Electrocoagulation set-up 

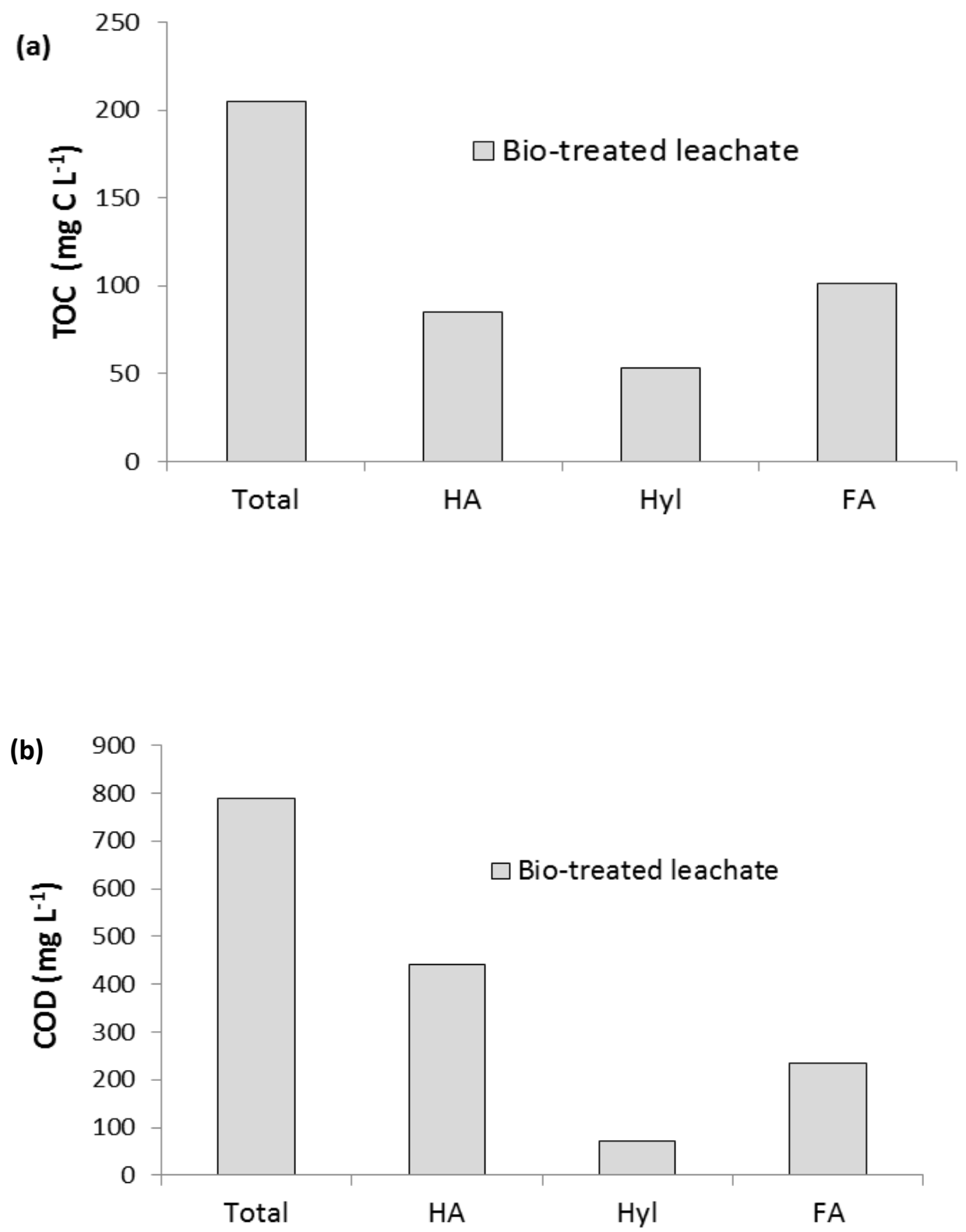
Fig. 2. Organic compounds fractionation of the bio-filtrated landfill leachate: a) TOC and b) COD 


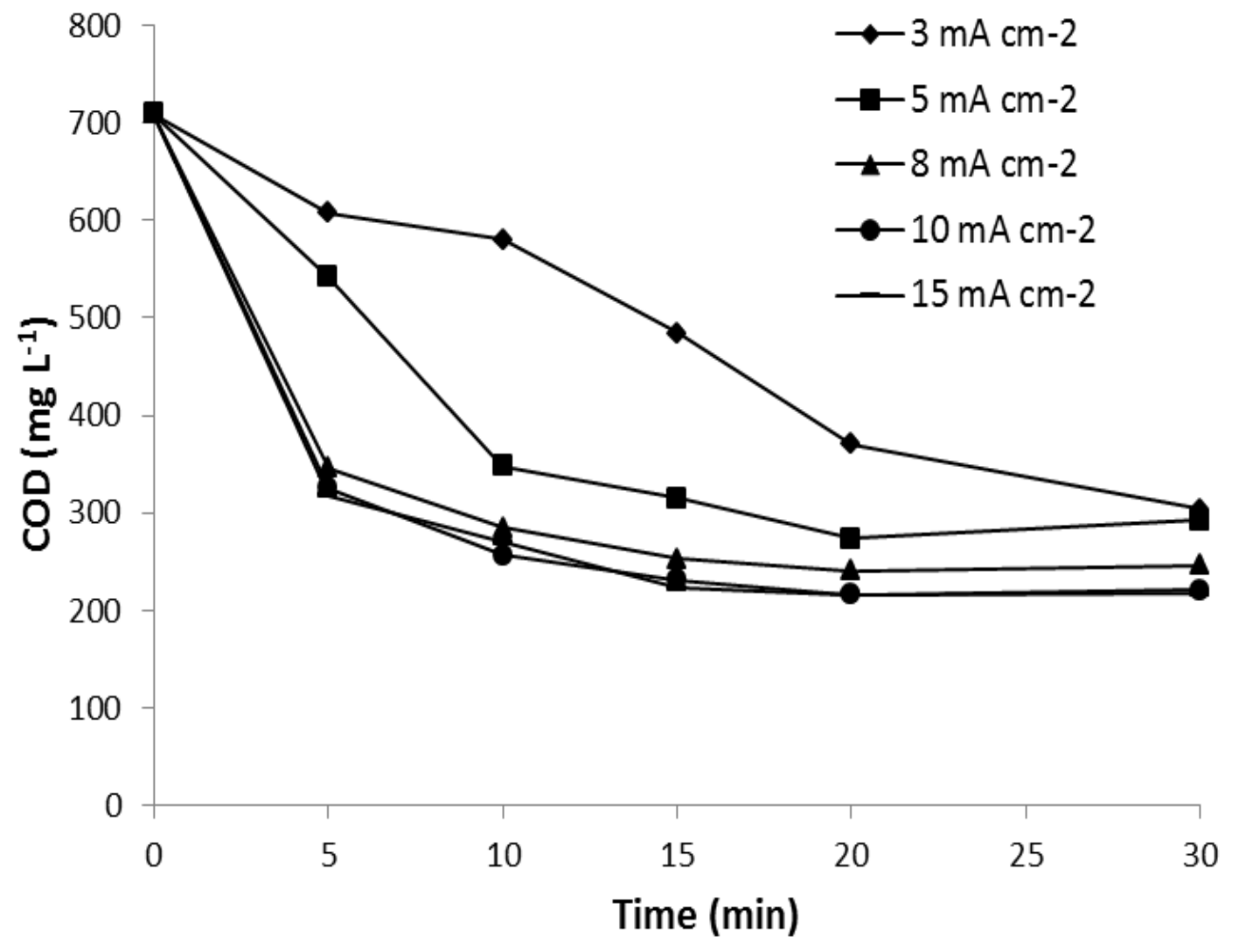


Fig. 3. Influence of current density and treatment time on COD removal (working volume $=1.5 \mathrm{~L}$, initial $\mathrm{pH}=8.66$, anode $=$ aluminum, cathode $=$ stainless steel $)$ 


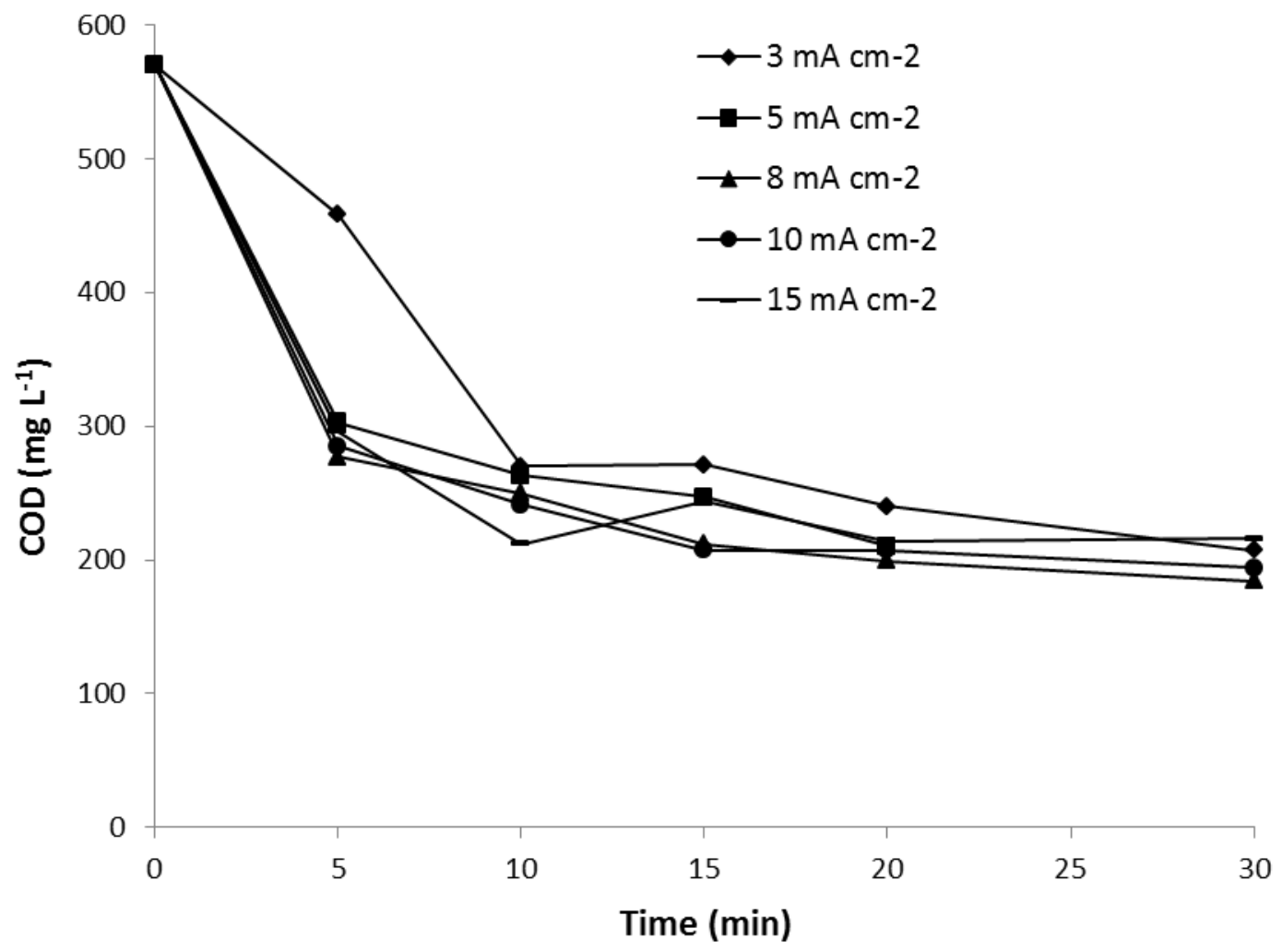


Fig. 4. Influence of current density and treatment time on COD removal (working volume $=1.5 \mathrm{~L}$, initial $\mathrm{pH}=8.94$, anode $=$ iron, cathode $=$ stainless steel) 

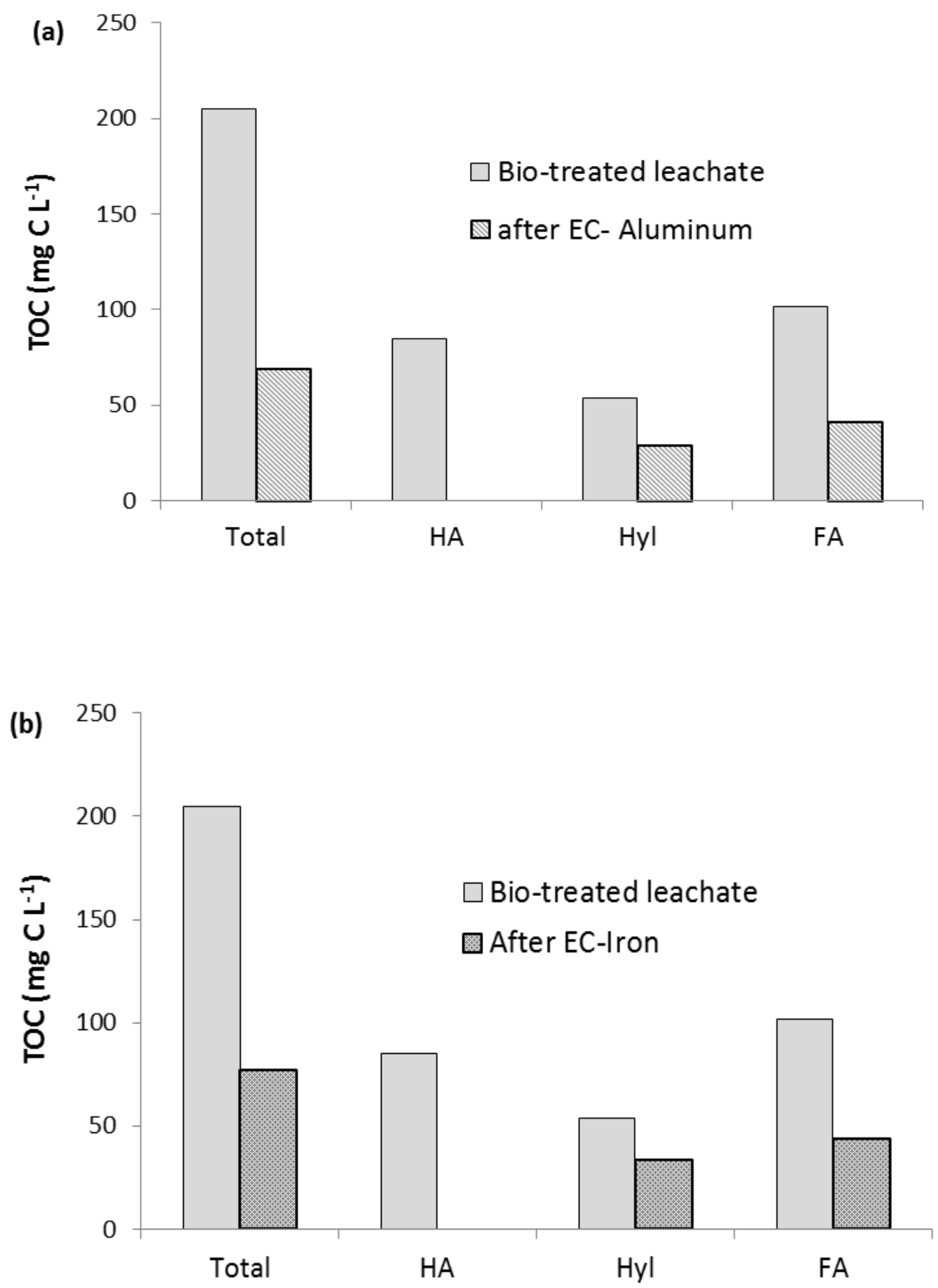
Fig. 5. TOC of different organic matter fractions before and after EC treatment: a) Aluminum anode, b) Iron anode: Conditions: $j=10 \mathrm{~mA} / \mathrm{cm}^{2}$ for aluminum and $8 \mathrm{~mA} / \mathrm{cm}^{2}$ for iron, $\mathrm{t}=20 \mathrm{~min}$, cathode $=$ stainless steel 

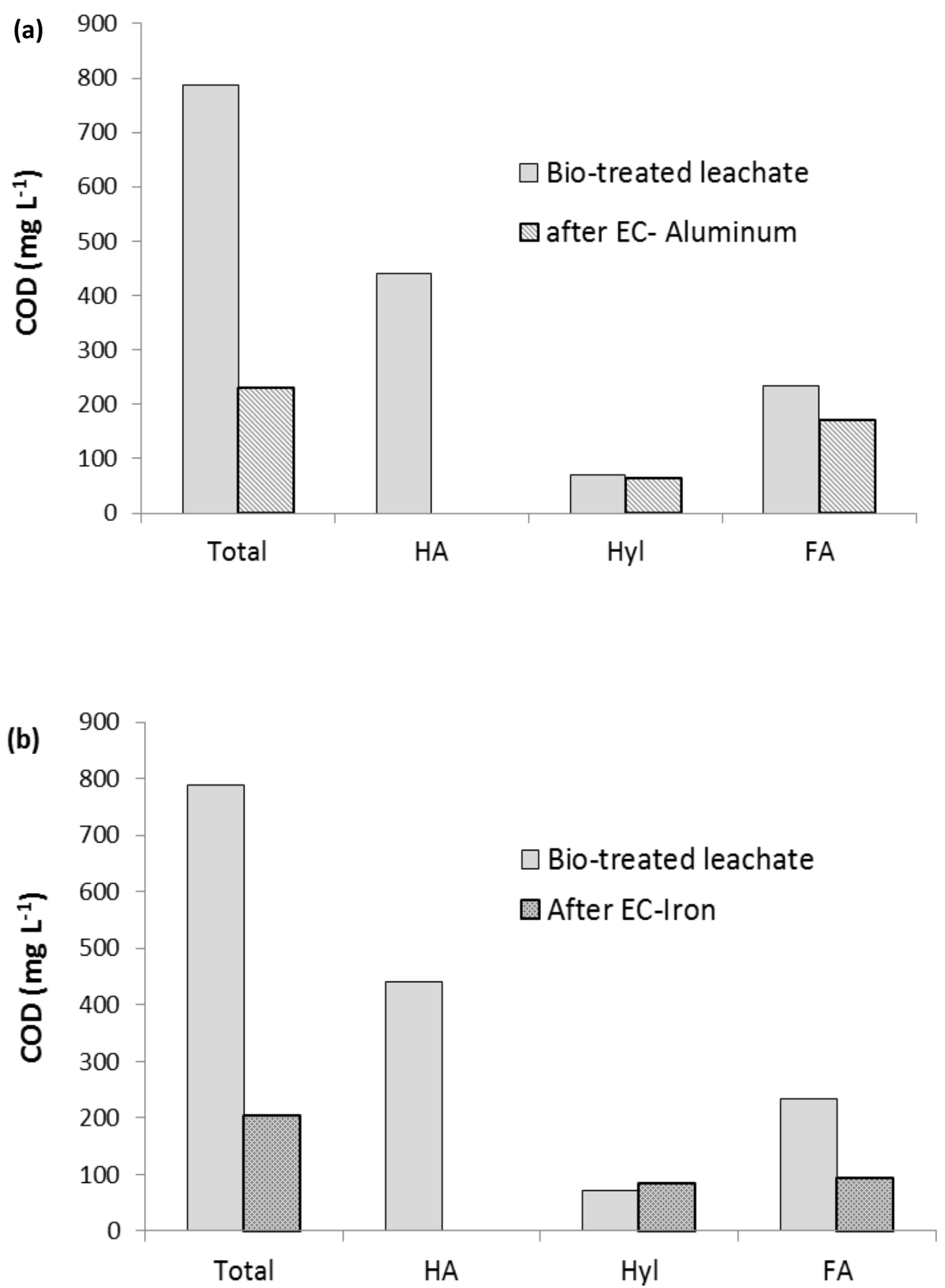
Fig. 6. COD of different organic matter fractions before and after electrocoagulation treatment: a) Aluminum anode, b) Iron anode: Conditions: $j=10 \mathrm{~mA} / \mathrm{cm}^{2}$ for aluminum and $8 \mathrm{~mA} / \mathrm{cm}^{2}$ for iron, $\mathrm{t}=20 \mathrm{~min}$, cathode $=$ stainless steel 


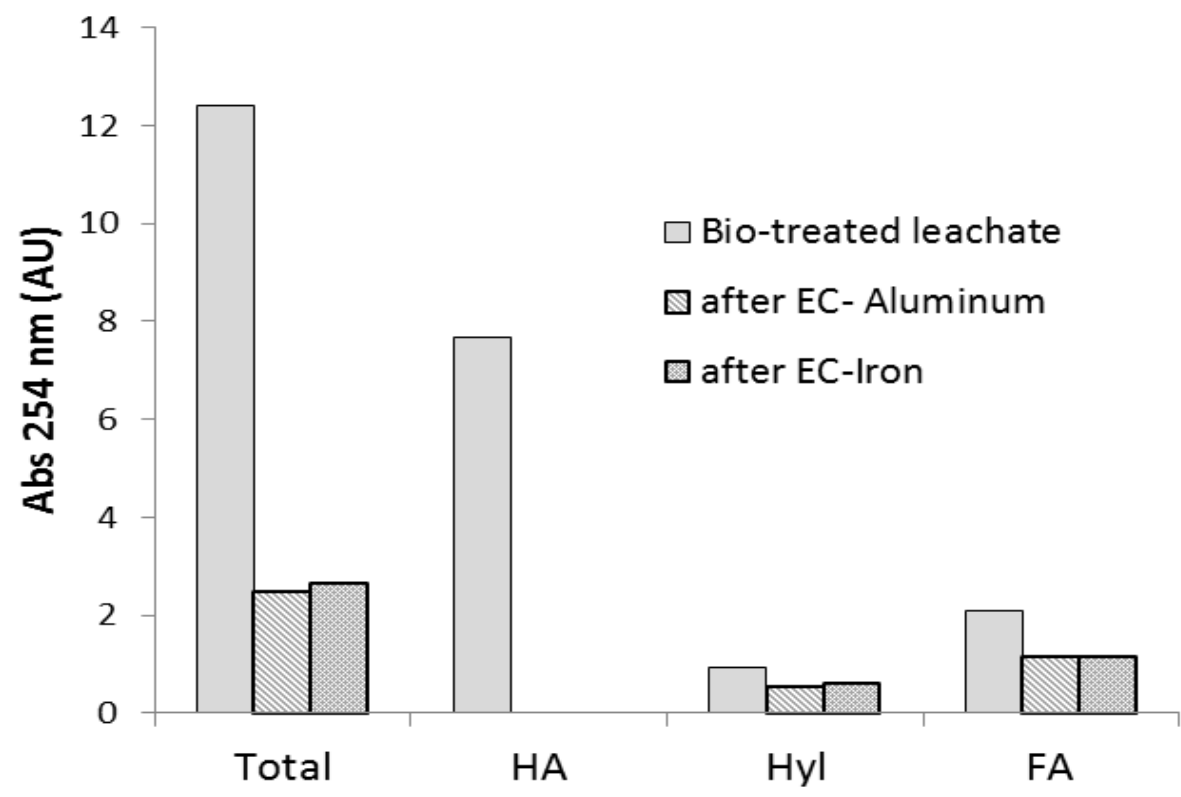


Fig.7. Absorbance at $254 \mathrm{~nm}$ of different organic fractions before and after EC treatment: Conditions $j=10 \mathrm{~mA} / \mathrm{cm}^{2}, \mathrm{t}=20 \mathrm{~min}$ for aluminum and $8 \mathrm{~mA} / \mathrm{cm}^{2}$ for iron, $\mathrm{t}=20 \mathrm{~min}$, cathode $=$ stainless steel 


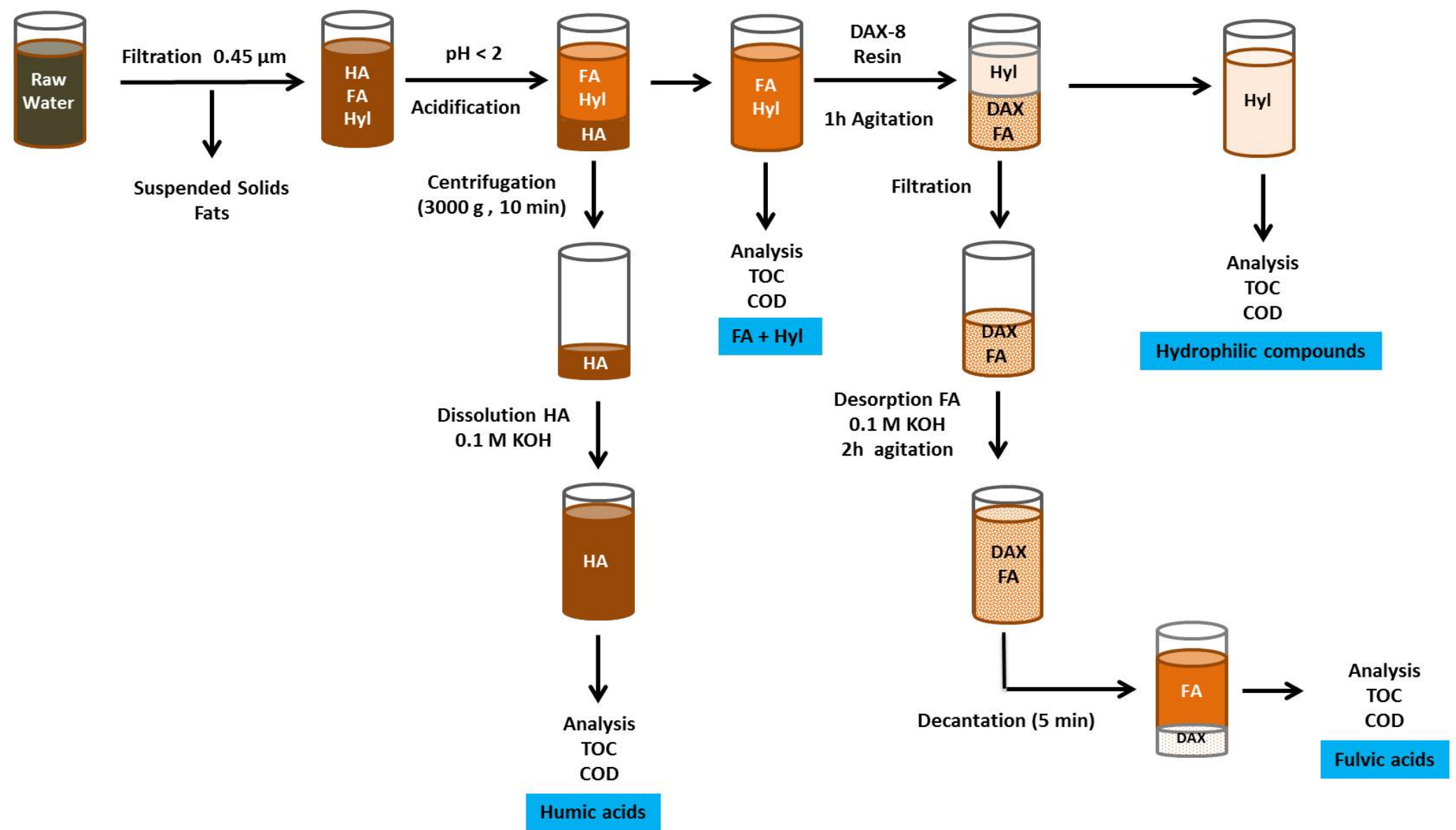


Fig. SM1. Different steps for the fractionation of organic matter in landfill leachate (adapted from (Van Zomeren and Comans, 2007) 
Van Zomeren, A., Comans, R.N., 2007. Measurement of humic and fulvic acid concentrations and dissolution properties by a rapid batch procedure. Environ. Sci. Technol. 41, 6755-6761. 


\begin{tabular}{cccccc}
\hline Parameters & Units & Average values & Min Values & Max values & $\mathbf{a}^{1}$ \\
\hline Total COD & & & & & \\
$\mathrm{BOD}_{5}$ & $\mathrm{mg} \mathrm{L}^{-1}$ & 596 & 204 & 1060 & 95 \\
$\mathrm{BOD} / \mathrm{COD}$ & $\mathrm{mg} \mathrm{L}^{-1}$ & 10.8 & 0.0 & 63 & 9 \\
Turbidity & - & 0.02 & 0.0 & 0.11 & 9 \\
Conductivity & $\mathrm{NTU}$ & 3.9 & 1.47 & 10.8 & 83 \\
pH & $\mathrm{mS} \mathrm{cm}^{-1}$ & 6.04 & 6.04 & 6.04 & 1 \\
Alkalinity & - & 8.7 & 8.1 & 9.19 & 100 \\
$\mathrm{~N}-\mathrm{NH}_{4}$ & $\mathrm{mg} \mathrm{CaCO}_{3} \mathrm{~L}^{-1}$ & 494 & 331 & 637 & 18 \\
$\mathrm{P}_{-} \mathrm{PO}_{4}$ & $\mathrm{mg} \mathrm{L}^{-1}$ & 13.1 & 0.0 & 64 & 83 \\
\hline
\end{tabular}

${ }^{1} \mathrm{a}=$ Number of analysis 
Table 1:

Bio-filtrated landfill leachate characteristics 